\author{
V. Lavrinenko, Kyiv, Ukraine, \\ V. Solod, Kamianske, Ukraine
}

\title{
THE RALATIONSHIP BETWHEEN THE PARAMETERS OF ROUGHNESS AND FEATURES OF SURFACE FORMATION WITH A SPECIAL MICROPROFILE
}

\begin{abstract}
This article shows the regularities of the formation of the relationship between the parameters of the roughness of the treated surface under the conditions of processing with a tool made of superhard materials. Features of formation of the ratio of height parameters of roughness $R_{\text {max }} / R_{a}$ for conditions of diamond-abrasive processing are shown. In general, in relation to $R_{\max } / R_{a}$ we have a kind of "roughness arc", when first for a normal untreated rough source surface it is close to 4, then abrasive-diamond treatment of this surface raises this ratio to 6 and then to 8, but further methods of abrasive finishing and polishing reduce the ratio to 6 and then chemical-mechanical polishing to a high-quality surface returns this ratio to values close to 4 . This means that if the initial cost of grinding the original surface affects the increase in the ratio, then the subsequent cost of finishing and polishing work reduces the value of the ratio $R_{\max } / R_{a}$ to the original. The peculiarities of obtaining a treated surface with a special microprofile, which is a flat protrusions with recesses (a kind of "pockets") for placing oil to increase the service life of such a surface.
\end{abstract}

Keywords: parameters of the roughness; the ratio of height parameters of roughness Rmax/Ra; special microprofile.

\section{INTRODUCTION}

An arithmetical average deviation from the mean line $R_{a}$ is a surface roughness parameter most widely accepted and used in scientific and technical publications. We point out that at one time GOST 2789-73 "Roughness of the surface. Parameters, characteristics and designations" indicated that the roughness parameters (one or more) are selected from the following nomenclature: $R_{a}-$ arithmetic mean deviation of the profile; $R_{z}$ is the height of the profile irregularities at 10 points; $R_{\max }$ is the highest profile height; $S_{m}$ is the average step of inequalities; $S$ - the average step of the local protrusions of the profile; $t_{p}$ is the relative reference length of the profile, where $p$ is the value of the cross-sectional level of the profile. Generalized data on the influence of various machining methods and modes using tools of superhard materials (SHM) on these parameters have not been adequately presented in the literature. Therefore, it is not clear which criteria should be used when deciding upon the machining processes in order to achieve the required $R_{a}$ value. Furthermore, the experience in commercial operation of products suggests [1] that for various applications more than one surface roughness parameter of contacting surfaces should be monitored: 
- $\quad R_{a}$ and the relative reference length of the profile irregularities $t_{p}$ for the parts that operate under the conditions of sliding and rolling frictions and for low-wear parts,

- $R_{a}$ and $t_{p}$ for the parts prone to contact stresses,

- $\quad R_{a}$ for press-fit joints,

- maximum height of irregularities $R_{\max }$, maximum peak height $R_{p}$ and mean spacing of the profile irregularities $S_{m}$ for the parts subjected to variable loads,

- $\quad R_{a}$ and $t_{p}$ for the parts that form tight joints.

In this case, it is also stated that the parameter $R_{a}$ is preferred. Thus, using this parameter, in [2] the classification of methods of abrasive processing (roughness) grinding (when $R_{a}$ is from $100.000 \AA$ to $1.000 \AA$ or from $10 \mu \mathrm{m}$ to $0.1 \mu \mathrm{m}$ ), lapping (when $R_{a}$ is from $1.000 \AA$ to $100 \AA$ or from $0.1 \mu \mathrm{m}$ to $0.01 \mu \mathrm{m}$ ), polishing (when $R_{a}$ is from $100 \AA$ to $1 A$ or from $0.01 \mu \mathrm{m}$ to $0.0001 \mu \mathrm{m}$ ).

\section{THE PURPOSE OF RESEARCH}

Note that there are such persistent misconceptions that the above parameters seem to exist independently and it is possible to obtain any desired value of one parameter and any desired value of another, or, for example, you can act on one parameter, and others will not change. The consequence of such misleading judgments is that researchers separately study the influence of processing regimes and conditions on specific roughness parameters, which introduces a system error, because in fact for the same processing conditions all roughness parameters are interconnected and affect only one parameter is impossible, because others will change. Therefore, the purpose of this article was to identify the features of the relationship between the roughness parameters and to establish how this may affect the achievement of a special microprofile of the treated surface.

\section{RESEARCH DATA}

We will illustrate this with a number of existing relationships between the parameters cited in the literature. Note that roughness is a statistical process, so such relationships are largely correlated. In [1], it was shown that the magnitude of the relationship or relationship between the parameters $R_{z}$ and $R_{a}$ can vary. The magnitude of this ratio depends on the profile of the roughness combs. Thus, for the triangular profile $R_{z} / R_{a}=4$. For convex and concave profiles, this ratio is larger and can reach up to 8 depending on the degree of convexity and concavity. Thus, the more the profile of the combs differs from the triangular one, the greater the $R_{z} / R_{a}$ ratio. Therefore, this ratio can be called as the coefficient of profile shape or the coefficient of completeness of the profile. It is known that the parameter $R_{z}$ cannot carry information about the shape of the comb. The parameter $R_{a}$ contains 
such information in an implicit form and only the ratio $R_{z} / R_{a}$ gives a numerical characteristic [1]. For specific processing conditions in a number of works the values of such relation are shown. Thus, to calculate the height characteristics of the roughness of the workpiece, you can use the following relations: $R_{\max }=k R_{z}$, where $k=1.25$ for irregular and $k=1.15$ for regular roughness. In this case, $R_{z} \approx 4 R_{a}$ for the rough surface and $R_{z} \approx 5 R_{a}$ for the surface in the range $R_{a}=1.25-0.02 \mu \mathrm{m}$. For conditions of processing by diamond-abrasive wheels: $R_{z}=5 R_{a}$. For turning with cutters: $R_{z}=5 R_{a}[1]$.

Let us now consider the correlation between $R_{a}$ and $R_{\max }$. Thus, for the conditions of diamond abrasive tool processing $-R_{\max }=(8-10) R_{a}$ [3]. For grinding conditions of coarse-grained CBN (160/125) steels 40X (HRC 53) and SHX15 (HRC 60) $-R_{\max }=(6.472 \pm 0.225) R_{a}$. For EDM conditions: $R_{\max }=5.40625 R_{a}[1]$.

Additionally, we pay attention to the correlation between the parameters: altitude $R_{a}$ and $R_{\max }$ and step $S_{m}$. In [3] it was shown that for most methods of machining at an average height of microroughnesses the step of roughness $S_{m}$ does not exceed $40 R_{\max }$ (grinding, planing, milling, boring of steel and cast iron parts), and for inequalities with a smaller height, their step values can reach $300 R_{\max }$. For the conditions of EDM: $S_{m}=14,1 R_{a}[1]$.

As we can see, the analysis of the literature refutes the constant misleading judgments about the independence of the roughness parameters. But there are other misleading judgments: about the constancy of the ratio $R_{\max } / R_{a}$ or that the step of microroughness $S_{m}$ increases with increasing parameter $R_{a}$. Let's look at these misleading judgments in more detail below.

The first misleading judgment is that the $R_{\max } / R_{a}$ ratio is constant and equal to 5 [4]. The theory of calculation of roughness parameters at grinding is based on this value of the relation. It would be possible to agree with this judgment, because the number 5 is quite decent, which we will show later, but why it is a constant, it is unclear. The identity of the slice thickness and the $R_{\max }$ parameter is even more unclear.

The second misleading judgment is that the $R_{\max } / R_{a}$ ratio is not constant and can vary in a wide range: very wide from 1.36 to 109.6 [5], or moderate from 1.42 to 18 [6]. The authors of [5] also indicated that the practice of abrasive treatment has shown that the ratio $R_{\max } / R_{a}$ during grinding mainly takes the value $4 \ldots 6$. This somehow explains the figure above in the first sentence -5 , as the average between 4 and 6 . But a little further in [5], its authors point out that in the case of abrasive polishing, the $R_{\max } / R_{a}$ ratio can take the value 30 . Let's understand - why such ranges and what it means.

Let's start with work [5]. It performs a theoretical analysis of the nature of the change in the ratio $R_{\max } / R_{a}$ for different conditions of abrasive treatment, and the grains are modeled in the form of a cone and a sphere. The authors assumed that 
the parameter $R_{\max }$ physically determines the slice thickness $a_{z}$ by a single grain. Further, the authors argue that during the transition from the cutting process to the process of grain friction with the processed material, the ratio of the height parameters of roughness $R_{\max } / R_{a}$ can vary widely - from 56 to 14 . It follows that the process of abrasive polishing can take place under these conditions at $R_{\max } / R_{a}=$ 30 , and, accordingly, $R_{\max } / R=0.07$, where $\mathrm{R}$ is the radius of the abrasive grain, $\mu \mathrm{m}$. When grinding, as we mentioned above, the ratio $R_{\max } / R_{a}$ takes smaller values (4...6), which corresponds to the values of $R_{\max } / R>0,6$. It is in these conditions, according to the authors [5], is a steady cutting process. That is, the lower the $R_{\max } / R_{a}$ ratio, the better the high-performance material removal. And when the transition from the cutting process to the process of friction of the grain with the processed material, the ratio $R_{\max } / R_{a}$ can take quite large values. Note that the assumptions of this work are certainly interesting and have a right to life. We will analyze them in more detail below. However, the results of theoretical studies of the ratio $R_{\max } / R_{a}$ from 1.36 to 109.6 are surprising.

Now let's deal with the work [6]. Here, too, we are faced with a fairly wide range of $R_{\max } / R_{a}$ ratios from 1.42 to 18 . But it should be noted that when the authors of [6] present the results of experimental studies of roughness, they are quite conscious and logical. Thus, with fine diamond grinding of glass, the ratio $R_{\max } / R_{a}$ is $7.2 \ldots 8.5$. When polishing stone with bound abrasive $R_{\max } / R_{a}$ is $4.2 \ldots 18$. When polishing glass $K 8 R_{\max } / R_{a}=7.8 \ldots 15.0$. But when we encounter in this work with modeling in the framework of the physical-statistical model, the results of calculations of the ratio $R_{\max } / R_{a}$ are surprising. Thus, for monocrystalline silicon carbide, this ratio is $1.5 \pm 0.1$. For the polishing of single-crystal sapphire the $R_{\max } / R_{a}$ ratio was $1.8 \ldots 2.0$ [6].

What is the conclusion from the above? Let's pay attention to $R_{\max }$. This is the highest altitude parameter. It is usually greater than $R_{z}$. In turn, $R_{z}$ is greater than $R_{a}$. How big? It is known: $R_{z} \square 4 R_{a}$ for a rough surface and $R_{z} \square 5 R_{a}$ for a polished surface. Can $R_{\max }$ and $R_{z}$ match? They can. However, $R_{\max }$ can never be less than $4 R_{a}$ for polished and polished surfaces, and in fact for all finishing surfaces. That is, the lower value of the ratio $R_{\max } / R_{a}=4$. And what is the upper value? In order to answer this question, we need to return to the conclusions of the work [5]. The authors of this work accepted that the parameter $R_{\max }$ physically determines the slice thickness $a_{z}$ by a single grain. Let's deal with this. If we accept the above statement, then when grinding, according to the authors [5] the value of $R_{\max } / R$ $>0.6$, where $R$ is the radius of the abrasive grain, $\mu m$. Let's see if this is so. To do this, take from work [1] table. 8.2 and slightly refine it (Table 1). 
Table 1 - Influence of the concentration of AC4 diamonds with MA coating in circles on the $\mathrm{BC}-\mathrm{E}$ polymer bond on the roughness indices during electrochemical grinding of $\mathrm{TH} 20$ alloy with a productivity of $525 \mathrm{~mm}^{3} / \mathrm{min}$

\begin{tabular}{|c|c|c|c|c|c|}
\hline \multirow[b]{2}{*}{ Characteristics of the wheel } & \multicolumn{3}{|c|}{ Roughness indicators } & \multirow[b]{2}{*}{$R, \mu m$} & \multirow[b]{2}{*}{$R_{\max } / R$} \\
\hline & $R_{a}, \mu m$ & $R_{\max }, \mu m$ & $R_{\max } / R_{a}$ & & \\
\hline $100 / 80-100$ & 0,36 & 2,75 & 7,64 & 45 & 0,061 \\
\hline$(100 / 80-100)+(50 / 40-25)$ & 0,63 & 2,99 & 4,75 & 40 & 0,075 \\
\hline $100 / 80-150$ & 0,40 & 3,29 & 8,23 & 45 & 0,073 \\
\hline
\end{tabular}

As you can see, the ratio $R_{\max } / R$ when grinding from table. 1 are significantly lower than 0.6 , and the ratio $R_{\max } / R_{a}$ correspond to those characteristic of grinding. So what determines the value of the ratio $R_{\max } / R_{a}$ when polishing up to 30 [5], or up to 18 [6]? Determines not $a_{z}$ [5], but scratches that occur during polishing on the treated surface. And these scratches occur due to the fact that, as we pointed out above, abrasive grains are not homogeneous. Any grain size has only $75 \ldots 80 \%$ of the main fraction, and up to $10 \%$ are grains of higher grain size. Similarly, the strength of SHM grains is not the same, because this indicator is subject to the logarithmically normal distribution law [1], and therefore the grain sample necessarily contains grains of higher grain size and greater strength, and therefore they cause scratches when polishing. In order to get rid of this, it is necessary to either further classify the powders of SHM grains, or to carry out the polishing process in several stages with a decrease in the grain size of the polishing paste.

Let us return to our $R_{\max } / R_{a}$ ratio. And what do the authors themselves suggest? Let's deal with this.

According to our data, this connection is generally reduced to simple relationships. For example, for the sintered and untreated surface of hard alloys, this dependence is close to the form $R_{\max } \square 4 R_{a}$. At blade processing of steels (40X, $\mathrm{SHX} 15, \mathrm{X} 12 \mathrm{M})$ with cutters from Hexanite-P the ratio corresponds more to the form of $R_{\max } / R_{a} \square 6$.

For abrasive treatment the most characteristic in this case will be the ratio close to the form of $R_{\max } / R_{a} \square 8$. This is typical both for the processing of tool materials: high-speed steels, tool ceramics, hard alloys (tungsten and tungsten), and for the processing of stainless steels, titanium alloys and joint processing of hardened and not Hardened steel (steel $10+9 \mathrm{HF}$ ). And can there be other variants of this relation for abrasive processing? We found that they can. The ratio $R_{\max } / R_{a}$ $\square 6$ is characteristic for abrasive processing of high-speed steels by circles of electrocorundum and diamond processing of magnetohard alloys, when a rougher surface is formed or its contribution to the height parameters are introduced by porosity. In general, it would probably be more correct to assume that for abrasive treatment (in a sufficiently wide range) the ratio $R_{\max } / R_{a}$ is closer to the form 
$R_{\max } / R_{a} \square 6-8$, and larger values are also characteristic of pure abrasive treatment methods. But when proving ceramics and coatings, the ratio is close to the form $R_{\max } / R_{a} \square 10$. In the latter case, the porosity of these materials contributes to the relative increase in the value of $R_{\max }$, because it already matters when proving it. The above allowed us to formulate the following position: the rougher the surface, the smaller the ratio between $R_{\max } / R_{a}$, and the more perfect the surface obtained by proving, polishing or other finishing methods, the greater the ratio. That is, for example, the sintered surface and the surface after abrasive treatment with conventional abrasives have the ratio $R_{\max } / R_{a}$ in the range (4-6). Processing with grinding wheels with SHM, when the surface has a lower roughness than after the above methods, and in fine grinding is mainly characterized by the ratio $R_{\max } / R_{a}$ $\square 8$. In the case of finishing operations on porous materials, when the values of $R_{a}$ are small, this ratio $R_{\max } / R_{a}$ is already close to 10 . Just in this case, the defects of the treated surface in the form of pores or scratches and is the reason for the increase in the value of this ratio.

Meanwhile, a number of further studies have shown that this conclusion is incomplete, as it reflects only the first part of this trend. It turns out that if we need to get an even more perfect surface after grinding, for example, polishing to obtain values of roughness values up to $5-10 \mathrm{~nm}$, ie the cost of the process of obtaining the surface increases, the value of the ratio $R_{\max } / R_{a}$ begins to decrease and reaches the situation when the above ratio becomes close to the form $R_{\max } / R_{a} \square 4$. That is, we have a kind of return to the original data in relation.

We will demonstrate the above on the example of forming a polished and polished surface of lithium tetraborate single crystal, a new promising material for functional electronics, the processing of which is very expensive, as it requires a final roughness for parameter $R_{a}$ within $1 \mathrm{~nm}$ [1]. After cutting the single crystal, its grinding was performed with a free abrasive with a decrease in the grain size of the abrasive and it would be logical to assume that the ratio $R_{\max } / R_{a}$, based on the above, will be within 6 (actually obtained: from 5.25 up to 6.25). Further polishing of lithium tetraborate single crystals was performed on resin polishers using two AFM diamond micropowders with a grain size of $2 / 1$ to $1 / 0$ and chromium oxide. This increases the cost of the process, but can significantly reduce the roughness of the treated surface of single crystals. For example, the roughness of the polished surfaces of single crystals after treatment with AFM 1/0 micropowder corresponds to $R_{a}$ in the range from $3.5 \mathrm{~nm}$ to $6.5 \mathrm{~nm}$. Subsequent use of chromium oxide during polishing can further reduce the roughness. Analysis of the polished surface by atomic force microscopy showed that in the lithium tetraborate single crystal in the plane (100) the microrelief has $R_{\max }, R_{z}$ and $R_{a}$, which are $5.26 \mathrm{~nm}, 4.82 \mathrm{~nm}$ and $1.24 \mathrm{~nm}$, respectively, and the ratio $R_{\max } / R_{a}$ is 4.25 . The above, just indicates that the more expensive the process of obtaining a high quality surface, the ratio $R_{\max } / R_{a}$ decreases to -4 . 
In general, in relation to $R_{\max } / R_{a}$ we have a kind of "roughness arc", when first for a normal untreated rough source surface it is close to 4 , then abrasive-diamond treatment of this surface raises this ratio to 6 and then to 8 , but further methods of abrasive finishing and polishing reduce the ratio to 6 and then chemicalmechanical polishing to a high-quality surface returns this ratio to values close to 4 . This means that if the initial cost of grinding the original surface affects the increase in the ratio, then the subsequent cost of finishing and polishing work reduces the value of the ratio to the original $-R_{\max } / R_{a}=4$.

Thus, the research showed that there is a possibility under certain conditions to fundamentally change the distribution of micro-irregularities on the treated surface, which will increase the fullness of its profile and form a surface with a kind of "oil pockets".

At one time in [7] it was shown that one of the ways to increase the technical and operational performance of the internal combustion engine is the formation on the surfaces of the cylinders of such an engine special microprofile, which is a flat alternating protrusions with recesses (peculiar "pockets") to accommodate the oil (Fig. 1). This increases the oil capacity and the bearing area of the treated surface. As a result, running-in time is reduced, lubrication costs are reduced, cylinder wear is increased and engine life is increased. It is established that the planar apex of such a surface is $50-66 \%$ at the level of the profile cross section $\mathrm{p}=1-2 \mu \mathrm{m}$ from the line of the maximum protrusion, the depth of the lines for oil placement is 2.5$10 \mu \mathrm{m}$. Surfaces of this type can be obtained by blunting the protrusions of the microprofile after pre-honing, as well as rolling the final treated surface.

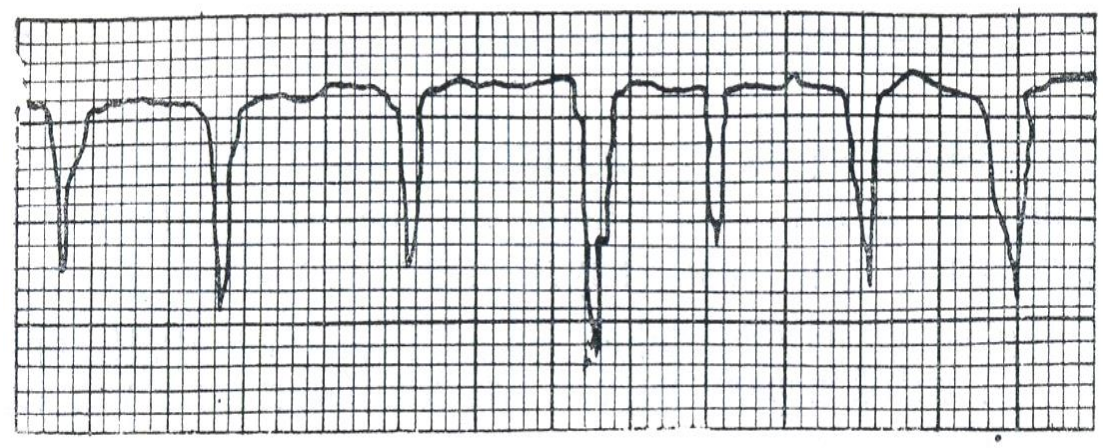

The question arises, is it possible to obtain approximately the same surface immediately in the grinding process without any additional refinement ? That is, is it possible to make a wheel at once to obtain a treated surface with "pockets" ? 
Our research has shown that this is possible, but for this we need to use a mixture of abrasives in the working layer. Thus, in [8] we once paid attention to the features of the tool with SHM, when the working layer of the wheel combines two or three grinding powders of different abrasives (diamonds and CBN), namely, additionally introduced into the working layer grinding powder compacts based on cubonite micropowders.

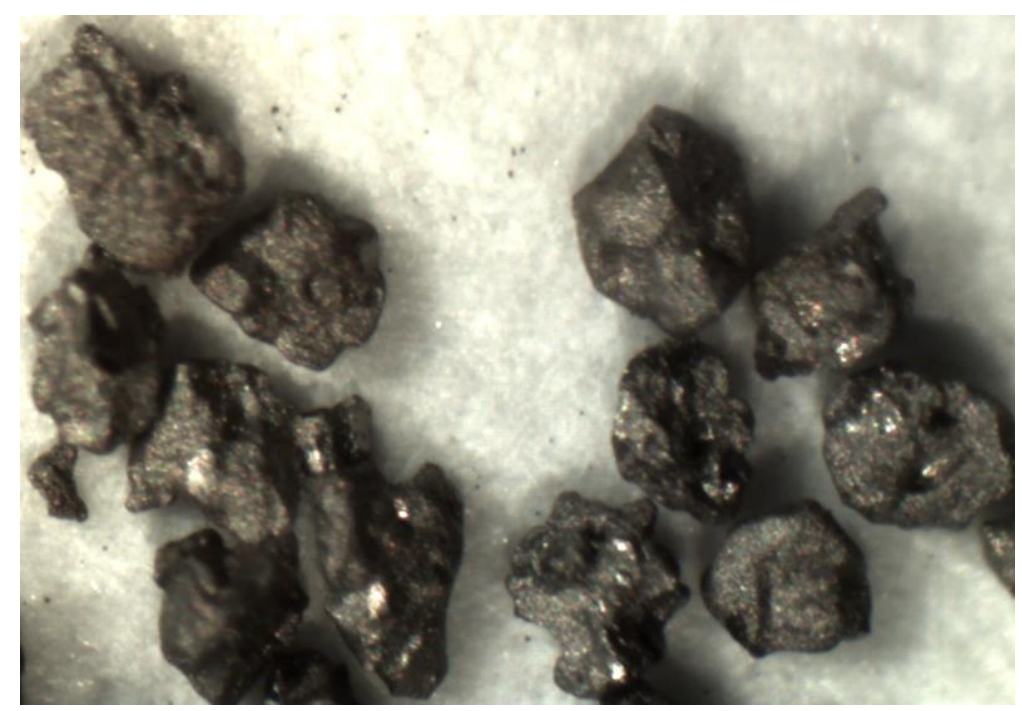

Figure 2 - General view of metallized grinding powders of compacts with grain size KM 400/315 from cubonite micropowders

These compacts have certain abrasive properties [8]. However, it should be noted that, probably due to the somewhat unusual (layered) wear of the grains of compacts, it is possible to form the original heterogeneous, unusual for the tradition. These wheels with SHM, the profile of micro-irregularities of the treated surface with the presence of peculiar "pockets" on the treated surface. However, attention was drawn to the fact that the above pure compacts are to some extent relatively "soft" and it was suggested that such compacts should be made more rigid due to their metallization (Fig. 2).

As the use of a mixture of grinding powders gives a certain effect, at the last stage for comparison the operational indicators of wheels were studied, when they use a mixture of KM compacts of different grain size and standard diamond grains 
of corresponding grain sizes. The surface roughness was investigated when using wheels with a mixture in the ratio of 50 to 50 grains from compacts with a grain size of KM 400/315 and the corresponding diamond grains of the AC32 brand. Thus, there is a situation that now only $50 \%$ of compacts are in the working layer, and the other $50 \%$ are diamonds, which on high-speed steel have a wear mechanism close to compacts, because on them Wear planes are also formed, and this is observed by the nature of micro-irregularities of the treated surface (Fig. 3).

$$
\text { R Profile }
$$

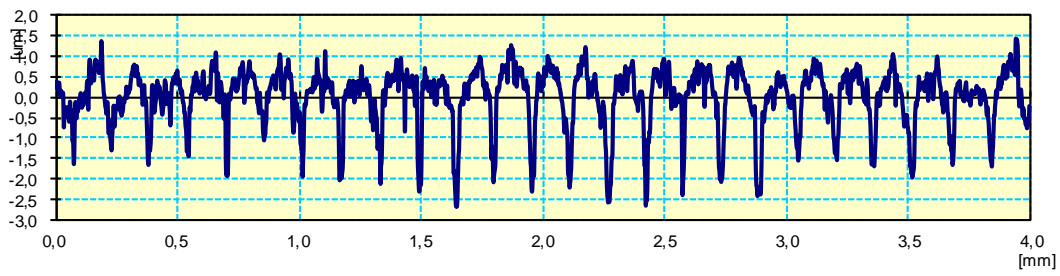

Figure 3 - The profile of microroughnesses of the processed surface in a wheel with a mix of grinding powders of the KM 400/315 compact and AC32 400/315 diamond

\section{SUMMARY}

Our research has shown that the ratio of roughness $R_{\max } / R_{a}$ is important to assess the distribution of the processing material in the rough layer, and thus to assess the possibility of forming a specific rough layer.

It is established that the simultaneous use of compacts and diamond grains in grain wheels may not improve the situation both in terms of wear resistance of the wheels and the quality of the treated surface, as it is impossible to achieve productive conditions for processing of high-speed steel. At the same time, it was found that with such a mixture in wheels it is possible to achieve a reduction in the roughness of the treated surface and the specific profile of micro-irregularities, when the so-called "oil pockets" are formed. That is, from the above it is clear that there is a real opportunity to implement in one wheels the conditions for obtaining a specific profile of micro-irregularities during grinding, when the so-called "oil pockets" are formed without any additional technological means.

References: 1. Lavrinenko, V.I. and Novikov, M.V., Nadtverdi abrazyvni materiali v mekhanoobrobtsi: entsiklopedichnii dovidnik [Superabrasive Materials in Machining Operations: Encyclopedic Handbook], Novikov, M.V., Ed., Kyiv: Inst. Sverkhtverd. Mater., Nats. Akad. Nauk Ukr., 2013. 
2. Puthanangady T. Recept Grinding Process Developments in the Optical Fiber Communication Industry // Gohram conferences : Precision Grinding \& Finishing in the Global Economy - 2001, Chicago, October, $1-3,2001$. 3. Some Specific Features Inherent in the Relation between the Roughness Parameters of a Treated Surface under Grinding Wheels with a Mixture of SHM Grinding Powders with Superficially Modified Grains / V.I. Lavrinenko, O.O. Pasichnyi, V.G. Poltoratskyi, V.Yu. Solod, V.L. Dobroskok, E.V. Ostroverkh. Journal of Superhard Materials, 2021, Vol. 43, No. 6, pp. 444-454. 4. Novikov, F.V., Vysokoprodyktuvne almazne shlifuvannia [High-performance diamond grinding]. Kharkiv: CHNEU, 2014. 412 p. 5. Novikov F.V., and Shkurupiy V.G. Vlijanie fornu rezyschih zeren pri abrazivnoj obrabotke na parametru sherohovatosti poverchnosti [Influence of the shape of cutting grains during abrasive treatment on the surface roughness parameters]. Fizicheskie $\mathrm{i}$ kompjuternue technologii. Trudy XXI Mezdunarodnoi nauchno-prakticheskoi konferencii. [Physical and computer technologies. Proceedings of the XXI International. scientific-practical conference], Kharkiv, 2015. pp. 3-13. 6. Fizichni zasadu formoutvorennia precizinuch poverkhon pid chas mechinicnoi obrobki nemetalevich materialov [Physical principles of forming precision surfaces during machining of non-metallic materials] Yu.D. Filatov, VI Sidorko, O.Yu. Filatov, S.V. Kovaliov. Kyiv: Nauk. dumka, 2017. 247 p. 7. Chepovetsky I.H. Mehanika kontaknogo vzaimodeistvija pri almaznoi obrabotke [Mechanics of contact interaction in diamond processing]. Kyiv: Nauk. dumka, 1978. 238 p. 8. Lavrinenko, V.I., Sytnyk, B.V., Poltorats'ky, V.G., Bochechka, O.O., and Solod, V.Yu., Composites based on $\mathrm{cBN}$ micron powders structured by carbon binder for the application as functional elements in the working layer of diamond-abrasive tools. Part 1. Composite grits as abrasive elements, J. Superhard Mater., 2014, vol. 36, no. 3, pp. 193-198.

\author{
Валерій Лавріненко, Київ, Україна, \\ Володимир Солод, Кам’янське, Україна
}

\title{
СПІВВІДНОШЕННЯ МІЖ ПАРАМЕТРАМИ ШОРСТКОСТІ I ОСОБЛИВОСТІ ФОРМУВАННЯ ПОВЕРХНІ ІЗ СПЕЦАЛЬНИМ МІКРОПРОФИЛЕМ
}

\begin{abstract}
Анотація. Викладені особливості зв'язку між основними висотними параметрами шорсткості $R \max$ ma $R_{a}$, a також між кроковим $S m$ та висотним параметрами $R_{a}$ при ториевому шліфуванні кругами з НТМ. Побутує такий досить стійкий міф, що вказані вище параметри як би незалежно існують самі по собі і можливо отримати будь-яке необхідне значення одного параметра і будь-яке бажане значення іншого, або, наприклад, можна подіяти на один параметр, а інші не зміняться. Наслідком такого міфу є те, що дослідники окремо вивчають вплив режимів і умов обробки на конкретні параметри шорсткості, чим вноситься системна похибка, оскільки насправді для однакових умов обробки всі параметри шорсткості пов'язані між собою і впливати тільки на один параметр є неможслиим, бо зміняться і інші. Тому метою даної роботи було показати як змінюється співвідношення між основними висотними показниками шорсткості $R_{\max }$ та $R_{a} i$ як ие може дозволити досягти умов формування поверхні iз спеціальним мікропрофілем при алмазній обробці. Показано, щяо вказаний зв'язок між вказаними параметрами шорсткості в цілому зводиться до простих відношень. Наприклад, для спеченої і необробленої поверхні твердих сплавів таке відношення близьке до вигляду $R_{\text {max }} / R_{a} \square 4$. При лезовій обробиі сталей різиями з Гексаніту-P відномення $R_{\max } / R_{a}$ вже $\epsilon \approx 6$. В иілому, ймовірно більш вірним було би вважати, шо для абразивної обробки (в достатньо широкій області) відношення $R_{\max } / R_{a}$ є більш близьким до вигляду $R_{\max } / R_{a} \approx(6-8)$, причому більші значення $\epsilon$ характерними $i$ для чистових методів абразивної обробки. А ось при доведенні кераміки $i$ покриттів це відношення зростає до $\approx 10$. В останньому випадку свій внесок у відносне підвищення значення Rтах вносить пористість даних матеріалів, оскільки при доведенні вона
\end{abstract}




\section{ISSN 2078-7405 Cutting \& Tools in Technological System, 2022, Edition 96}

вже має значення. Наведене вище дозволило нам сформулювати таке положення: чим більш грубою є поверхня, тим вона має менше відношення між $R_{\text {max }} / R_{a}$, а чим більш довершеною $\epsilon$ поверхня, отримана доведенням, поліруванням або іншими фінішними методами, тим ие відношення є більшим. Тобто, наприклад, спечена поверхня і поверхня після абразивної обробки звичайними абразивами має відношення в діапазоні $R_{\text {max }} / R_{a} \approx(4-6)$. Обробка шліфувальними кругами з НТМ, коли поверхня має меншу шорсткість, аніж після наведених вище методів, і при тонкому шліфуванні переважно характеризується зростанням відношення до $\approx 8$. У випадку доводочних операчій на пористих матеріалах, коли значення Ra є невеликими, це відношення $\epsilon$ вже близьким до $R_{\max } / R_{a} \approx 10$. Як раз в цььому випадку дефекти самої обробленої поверхні $у$ вигляді пор або подряпин і є причиною підвищення величини даного відношення. Між тим, низка подальших досліджень засвідчила, що такий висновок є неповним, оскільки відбиває тільки першу частину вказаної тенденції. Виявляється, що якщо нам необхідно отримати ще більш довершену поверхню після шліфування, наприклад, поліруванням з отриманням значення величин шорсткості до 5-10 нм, тобто витрати на прочес отримання поверхні зростають, то величина відношення $R_{\max } / R_{a}$ починає знижатися $i$ досягає тієї ситуачії, коли вказане вище відношення стає близьким к вигляду $R_{\text {mах }} / R_{a} \approx 4$. Тобто у нас відбувається своєрідна «дуга відношення висотних параметрів». Наведені дослідження дозволили виявити умови формування спеціального мікропрофіля оброблюваної поверхні при алмазному шліфуванні. Так, одночасне застосування в кругах зерен компактів і алмазних зерен ситуацію може не поліпшувати як $з$ точки зору зносостійкості кругів так $і$ якості обробленої поверхні, оскільки є неможливим досягти умов продуктивної безприпальної обробки швидкорізальної сталі. Разом з тим, виявлено, що саме при такій суміші в кругах і є можливим досягти зниження шорсткості обробленої поверхні і того специфічного профілю мікронерівностей, коли утворюються так звані „масляні кишені”. Тобто встановлено, що є реальна можливість реалізувати в одному крузі умови отримання при шліфуванні специфічного специфічного профілю мікронерівностей, коли утворюються так звані „масляні кишені” без будь-яких додаткових технологічних засобів. Ключові слова: параметри шорсткості; співвідношення між висотними параметрами $R_{\text {max }} / R_{a}$; спеціальний мікропрофіль. 